\title{
OPEN
}

\section{Author Correction: Cytokine storms are primarily responsible for the rapid death of ducklings infected with duck hepatitis $A$ virus type 1}

Jinyan Xie, Mingshu Wang, Anchun Cheng, Xin-Xin Zhao, Mafeng Liu, Dekang Zhu, Shun Chen, Renyong Jia, Qiao Yang, Ying Wu, Shaqiu Zhang, Yunya Liu, Yanling Yu, Ling Zhang, Kunfeng Sun \& Xiaoyue Chen

Correction to: Scientific Reports https://doi.org/10.1038/s41598-018-24729-w, published online 26 April 2018

This Article contains errors in the Materials and Methods section, under the subheading 'Viral RNA load in the liver and cytokine expression in the liver and blood'.

"Amplification was performed in $10-\mu \mathrm{l}$ reaction volumes containing $0.5 \mu \mathrm{l}$ of each primer and $1 \mu \mathrm{l}$ of RNA"

should read:

"Amplification was performed in $10-\mu \mathrm{l}$ reaction volumes containing $0.5 \mu \mathrm{l}$ of each primer and $1 \mu \mathrm{l}$ of cDNA"

In addition, this Article contains errors in Reference 46 which was incorrectly given as:

$\mathrm{Ou}, \mathrm{X}$. et al. The neglected avian hepatotropic virus induces acute and chronic hepatitis in ducks: an alternative model for hepatology. Oncotarget, (2017).

The correct reference is listed below as ref. 1:

\section{Reference}

1. Ou, X. et al. The Neglected Avian Hepatotropic Virus Induces Acute and Chronic Hepatitis in Ducks: An Alternative Model for Hepatology. Oncotarget 8, 81838-81851, https://doi.org/10.18632/oncotarget.19003 (2017).

(i) Open Access This article is licensed under a Creative Commons Attribution 4.0 International cc) License, which permits use, sharing, adaptation, distribution and reproduction in any medium or format, as long as you give appropriate credit to the original author(s) and the source, provide a link to the Creative Commons license, and indicate if changes were made. The images or other third party material in this article are included in the article's Creative Commons license, unless indicated otherwise in a credit line to the material. If material is not included in the article's Creative Commons license and your intended use is not permitted by statutory regulation or exceeds the permitted use, you will need to obtain permission directly from the copyright holder. To view a copy of this license, visit http://creativecommons.org/licenses/by/4.0/.

(C) The Author(s) 2020 